\title{
Japan's position in international climate policy: navigating between Kyoto and the APP
}

\author{
Harro van Asselt • Norichika Kanie • Masahiko Iguchi
}

Accepted: 27 May 2009/Published online: 24 June 2009

(C) The Author(s) 2009. This article is published with open access at Springerlink.com

\begin{abstract}
The emergence of technology-oriented agreements such as the 2005 AsiaPacific Partnership on Clean Development and Climate (APP) may have significant implications for the future of global climate governance, as these agreements could be perceived as an alternative for the existing international climate regime. It is, therefore, important to examine what has moved countries to be involved in these agreements alongside the UN climate regime. This article seeks to identify possible factors contributing to Japan's participation in both the UN climate regime and the APP, looking at the position of domestic interest groups, the distribution of climate policy-making at the government level and varying international pressures. It concludes that Japan's participation in both the APP and the UN climate regime flows from a policy-making process that tries to accommodate conflicting viewpoints at the domestic and international levels. To what extent Japan's participation in both fora can be regarded as constructive will depend on the partnership's ability to support the implementation of a future climate regime.
\end{abstract}

Keywords Asia-Pacific Partnership on Clean Development and Climate . Climate governance · Japan · Kyoto Protocol · Post-2012 climate policy · UNFCCC

\section{Introduction}

Global governance in the field of climate change is characterised by an increasing diversity in arrangements that aim to address the problem. While the bulk of international rules addressing climate change is still to be found in the 1992 United Nations Framework

H. van Asselt ( $($ )

Department of Environmental Policy Analysis, Institute for Environmental Studies,

Vrije Universiteit Amsterdam, De Boelelaan 1087, 1081 HV Amsterdam, The Netherlands

e-mail: harro.van.asselt@ivm.vu.nl

N. Kanie - M. Iguchi

Department of Value and Decision Science, Graduate School of Decision

Science and Technology, Tokyo Institute of Technology, Tokyo, Japan 
Convention on Climate Change (UNFCCC) and its 1997 Kyoto Protocol, a plethora of novel governance arrangements has emerged in the last few years, involving not only nation states but also non-state actors including business, civil society and local and regional government authorities (Jagers and Stripple 2003; Bäckstrand 2008; Pattberg and Stripple 2008; Biermann et al. 2009, in press). Some of these arrangements involve governments that are at the same time engaged in climate change negotiations under the UN umbrella. The question then arises what the relation is between the commitments of these governments under the UN framework and their activities in other fora. Against this background, the aim of this article is to identify the underlying factors that moved one country, Japan, to position itself in between the UN climate regime and one of the most prominent new governance arrangements, the Asia-Pacific Partnership on Clean Development and Climate (APP).

Less than half a year after the Kyoto Protocol had entered into force, six countries- the United States, Japan, Australia, China, India and the Republic of Korea-announced the APP in July 2005 (see Karlsson-Vinkhuyzen and van Asselt 2009, this issue). The countries proposed to address climate change mitigation and a range of other concerns through a voluntary, non-legally binding and technology-oriented approach. In 2007, the group was joined by Canada. In contrast to the Kyoto Protocol with its focus on absolute greenhouse gas emission reduction targets, the APP focuses primarily on the development and deployment of clean technologies in combination with market-based instruments such as emissions trading. Although its founders stressed that the APP was 'complementary' to the Kyoto Protocol, there has been debate over the extent to which it actually was formed to become an alternative to the legally binding framework under the Protocol (McGee and Taplin 2006; Christoff and Eckersley 2007; Lawrence 2007; van Asselt 2007).

When the Partnership was established, Japan was in a unique position as it was the only country in the APP group that at the same time had committed to a greenhouse gas emission reduction commitment under the Kyoto Protocol. Australia and the United States were also among the developed (Annex I) countries in the UNFCCC, but had refrained from ratifying the Kyoto Protocol. China, India and the Republic of Korea had ratified the Protocol, but were not subject to legally binding quantified emission reduction commitments. Japan, in contrast, had committed itself under the Protocol to reduce its greenhouse gas emissions by 6\% from 1990 levels between 2008 and 2012. As a participant in both agreements, Japan thus has a high stake in the direction of the future (post-2012) institutional framework on climate change. In that sense, it is not alone anymore, as Canada, which joined the APP later, is also bound by a binding emission reduction commitment under the Kyoto Protocol. Furthermore, after a change of government at the end of 2007, Australia also ratified the Kyoto Protocol. Still, Japan's position is noteworthy for several reasons. First, the country has a special interest in the success of the Kyoto Protocol, with the treaty being named after the former capital city. ${ }^{1}$ Second, Japan played a critical role in forging consensus on the Bonn Agreement in 2000-2001, when there was mounting concern regarding the future of the Kyoto Protocol due to the United States' decision not to ratify (Broadbent 2002). ${ }^{2}$ Third, Japan is one of the world's major emitters of greenhouse gases, and is the secondlargest economy in the world. Fourth, the country has historically attempted to maintain

\footnotetext{
1 Tiberghien and Schreurs (2007, p. 88) note the symbolic importance of the fact that the agreement was concluded in a Japanese city.

2 The Bonn Agreement, which was reached in 2001 at the second part of the sixth Conference of the Parties to the UNFCCC (COP-6bis), managed to provide new impetus to the climate regime, after negotiations at COP-6 in The Hague in 2000 failed.
} 
good relations with the main non-Party to the Kyoto Protocol, the US (Matsumura 2000; Miyaoka 2004). Fifth, Japan has interests in exerting political leadership in Asia, as the region 'is the basis for its economic activities as well as for establishing an appropriate position in international society' (Matsumura 2000, p. 66).

This article seeks to explain why Japan navigates between the UN climate regime and the APP and to shed some light on the country's position in the negotiations under the UNFCCC about a future institutional framework for climate change policy. Japan has neither fully embraced Kyoto's cap-and-trade approach nor has it outright rejected it in favour of technology-oriented governance arrangements such as the APP. This article explores different possible explanations, looking at the position of domestic interest groups, the distribution of climate policy-making competencies at the government level and varying international pressures. It concludes that Japan's participation in both fora is the result of a difficult process of trying to accommodate conflicting viewpoints at the domestic and international levels. Furthermore, depending on the extent to which the APP is able to support the implementation of a post-2012 climate regime, the decision to be involved in both the APP and the UN climate regime might actually be seen as conducive to the effectiveness of global climate governance.

The article is structured as follows. Section 2 provides an overview of the current state of affairs in Japanese domestic climate policy. Section 3 examines Japan's role in the UN climate regime and initiatives outside of it, paying specific attention to the APP. Section 4 then moves on to investigate the factors that contributed to Japan's participation in both the APP and the Kyoto Protocol. Finally, Sect. 5 summarises the analysis, and provides some concluding thoughts.

\section{Japanese domestic climate policy: an overview}

Japan is one of the largest greenhouse gas emitters in the world, after the United States, China, the EU-25, Russia and India (Baumert et al. 2005, p. 12), and its emissions are still on the rise. In 2006, Japan's greenhouse gas emissions grew by $6.2 \%$ from their 1990 levels (MOE 2008). As Japan's Kyoto target is $-6 \%$ from 1990 levels, this means that Japan is now obliged to cut emissions by $12.2 \%$ from 2006 levels during the first commitment period of the Kyoto Protocol. Although the Japanese population has started to decrease since 2005, the rise in greenhouse gas emissions is still expected to continue. Additional measures are thus required to achieve the $6 \%$ reduction target (Kameyama 2008).

Climate change policy in Japan evolved in response to international policy developments. After the Kyoto Protocol was adopted in 1997, the Guideline of Measures to Prevent Global Warming was announced in June 1998 (MOE 1998) by the newly established Global Warming Prevention Headquarters, which was headed by the prime minister, and was mandated to coordinate policy measures among relevant ministries and government agencies. This Guideline formed the core of Japan's climate policy. It did not introduce new policy measures, but was rather a list of existing policies at the time, as the operational details of the Kyoto Protocol had not yet been made clear. The Guideline was revised in June 2002 after the Marrakech Accords were agreed upon in 2001. The revised Guideline took a step forward in setting emission reduction targets and introducing policy measures for different sectors. The next step was taken after the Kyoto Protocol's entry into force on 16 February 2005. The Kyoto Protocol Target Achievement Plan was introduced in April 2005 'in order to stipulate the measures necessary to reliably achieve 
the target of a $6 \%$ reduction promised by Japan under the Kyoto Protocol' ${ }^{3}$ By then, the Plan included more detailed policies and measures. It reported that the industrial sector had made some progress, while other sectors such as transportation, households and business were considered to be areas where emission reductions still needed to be attained.

More than a decade after their establishment, the Headquarters have not yet been able to exert strong leadership in coordinating between the different ministries with a view to agreeing on a common, consolidated climate policy position (Fisher 2004; Kameyama 2008). Traditionally, there have been two conflicting perspectives within the country, which have developed in parallel and have been advocated by different ministries, namely the powerful Ministry of Economy, Trade and Industry (METI) and the Ministry of Environment (MOE) (e.g. Takeuchi 1998; Kawashima 2000; Fisher 2004; Oshitani 2006). In addition, the Ministry of Foreign Affairs (MOFA) coordinates the country's international position on climate change, meaning that there are thus three main players at the government level. METI has a strong history of contributing to the economic growth of the Japanese industry sector, making it one of the most competitive in the world, and it has acted as an important contact point between industry and government bureaucracy. One of its main interests has been to protect and promote the competitiveness of the Japanese industry. MOE, on the other hand, is a relatively young institution. Established in 1971 as an agency, it was upgraded to a ministry only in 2001. MOE is responsible for coordinating environmental affairs. However, it is in a rather weak position compared to other ministries, due to its low financial and human resources. Therefore, MOE is often not able to effectively coordinate government deliberations on environmental issues. Due to the substantive differences in position between the three ministries involved and the lack of effective coordination mechanisms, the government's foreign policy on climate change has been both ambiguous and fragmented (Takeuchi 1998; Hattori 1999). At times, Japan put itself in an awkward position, having two distinct speakers with different views speaking up on behalf of the same government in the international negotiations. The run-up to the Kyoto conference in 1997 was an important exception in this context, as the Prime Minister's Cabinet Office intervened in the process and forged a common position just in time before the summit.

These diverging views notwithstanding, there are some signs of progress. Japanese Prime Ministers in the past few years have each taken action on the issue of climate change (see Table 1). Most notably, in 2008, Prime Minister Fukuda announced a long-term Japanese emission reduction target of $60-80 \%$ from current levels by 2050 , after having been criticised by international NGOs for rejecting a strong quantified emission reduction commitment at the climate conference in Bali in 2007. In addition, the discussions on a Japanese emissions trading scheme have picked up steam. Following Fukuda's initiative, a trial emissions trading scheme was started in 2008 (Fukuda 2008). The Japanese government has not been able to agree on a medium-term target for the country going beyond its Kyoto cap, in contrast with, for example, the EU. Nevertheless, Environment Minister Tetsuo Saito proposed in January 2009 that Japan should set a medium-term target of reducing its emissions within the range of $25-40 \%$ as suggested by the Fourth Assessment Report of the Intergovernmental Panel on Climate Change (IPCC AR4), and this issue is at present under consideration. ${ }^{4}$

\footnotetext{
3 Kyoto Protocol Target Achievement Plan. Retrieved January 20, 2009, from http://www.kantei.go.jp/ foreign/policy/kyoto/050428plan_e.pdf.

4 Mainichi Shinbun, 30 January 2009.
} 
Table 1 Japanese Prime Ministers and domestic climate policy

\begin{tabular}{|c|c|c|}
\hline Period & Prime Minister & Main climate policy initiatives \\
\hline $\begin{array}{l}\text { April 2001- } \\
\text { September } 2006\end{array}$ & $\begin{array}{l}\text { Junichiro } \\
\text { Koizumi }\end{array}$ & $\begin{array}{l}\text { Initiated the 'Cool Biz Campaign': wear no tie in summer } \\
\text { and warm clothes in winter } \\
\text { Failed in attempt to introduce climate change-motivated } \\
\text { environmental tax }\end{array}$ \\
\hline September 2006-2007 & Shinzo Abe & $\begin{array}{l}\text { Introduced 'Cool Earth 50': halving global greenhouse gas } \\
\text { emissions by } 2050 \text { from 'current' levels }\end{array}$ \\
\hline September 2007-2008 & Yasuo Fukuda & $\begin{array}{l}\text { Introduced the 'Fukuda Vision', which includes the } \\
\text { introduction } \\
\text { of a pilot emission trading scheme in autumn } 2008 \text {; } \\
\text { a long-term target of } 60-80 \% \text { emission reductions from } \\
\text { current levels by } 2050 \text {; and the pre-announcement of a } \\
\text { mid-term target }\end{array}$ \\
\hline September 2008-present & Taro Aso & $\begin{array}{l}\text { Establishment of a 'Mid-term Target Committee'(Cabinet } \\
\text { Secretariat) }\end{array}$ \\
\hline
\end{tabular}

In sum, it can be seen that Japanese domestic climate policy has been characterised by difficulties in achieving consensus between government actors. However, policy developments have inched forward by initiatives taken by consecutive Prime Ministers. Most notably, Japan's long-term 'vision' is the result of Shinzo Abe's 'Cool Earth 50' plan, whereas Prime Ministers Fukuda and Aso have made first steps towards introducing a domestic emissions trading scheme and setting a mid-term target.

\section{Japan and international climate policy}

Having sketched the domestic context for Japanese climate policy, we now move on to Japan's position in international discussions on future international climate governance. We first describe Japan's position in the UNFCCC negotiations. We then explore Japan's role in other initiatives, most notably the Major Economies Process and the Group of 8 (G8) process, which both played an important role in bringing the climate change issue to the attention of Japanese Prime Ministers. Finally, we provide an overview of Japan's involvement in the APP.

\subsection{Japan and the post-2012 UN climate negotiations}

Starting with the Montréal summit in 2005, questions about the shape of global climate governance beyond 2012 have moved to centre stage in the UNFCCC process. Particularly important in this regard is the issue of mid-term and long-term target setting. Negotiations on a follow-up agreement to the Kyoto Protocol were formally launched at the 13th UNFCCC Conference of the Parties (COP) in Bali, Indonesia in December 2007. After intense negotiations, Parties to the UNFCCC finally adopted a series of decisions together referred to as the 'Bali Road Map'. The key decision, known as the Bali Action Plan (UNFCCC 2008a, b), constitutes an important landmark in the development of international climate policy. However, the decision avoids any explicit reference to a quantitative elaboration of a long-term objective, and does not go further than calling for 'deep [emission] cuts'. It also does not indicate specific ranges for short- to medium-term targets as the IPCC AR4 suggested. Japan, together with the United States and Canada, was 
initially one of the countries opposing the inclusion of any numerical targets in the decision, although it changed its position after the Bali conference (Clémençon 2008). The decision leaves open a wide range of possibilities of how a post-2012 agreement might look, and does not clarify whether such an agreement will include binding emission reduction targets for developed countries (Rajamani 2008).

In its submissions to the various bodies under the UNFCCC, Japan has provided an outline of its post-2012 negotiating position. First, in line with the 'Cool Earth 50' strategy, the Japanese government has proposed a non-legally binding 'shared long-term vision' of at least halving global greenhouse gas emissions by 2050 (UNFCCC 2008c, d). Second, Japan emphasises the importance of promoting technological innovation through, among others, expanding investment in research and development, and strengthening frameworks for international cooperation (UNFCCC 2008c). Third, Japan has been one of the staunchest supporters of including a 'sectoral approach' in a future climate agreement. What exactly it meant with such an approach was long unclear, but recent submissions shed some light on Japan's ideas (UNFCCC 2008c, d). Essentially, under the 'cooperative sectoral approach' envisaged by Japan, countries would engage in a bottom-up process of setting quantified mid-term emission reduction targets, by aggregating abatement in a number of sectors. Such calculations could then serve as a basis for negotiating numerical caps for all the countries. These sectoral emission reduction potentials are in turn calculated by factors such as the technology to be used, mitigation potential and expected production. The sectoral approach also entails identifying 'best practices' for each sector and conducting technology needs assessments in developing countries. Whether the sectors would be assigned specific targets remains unclear. Fourth, Japan has called for 'meaningful participation' of all the major emitters (UNFCCC 2007). In this context, it favours differentiation among developing (non-Annex I) countries on the basis of specific criteria (e.g. income per capita and share of global emissions). The sectoral approach proposed by Japan applies to both developed and developing countries-in particular the major emitters-although different economic and geographical circumstances are taken into account (UNFCCC 2008c). The Japanese push for a sectoral approach stems from the concern that the country's leading import and export markets are China and the US, which both do not have binding numerical targets under the current climate regime. Furthermore, the sectoral approach allows Japanese actors to emphasise their relative high efficiency-and hence, limited potential for further emissions abatement-in certain sectors.

The various elements proposed by Japan in the context of the UNFCCC negotiations also play an important role in the country's activities in non-UN initiatives, as we will see below.

\subsection{Japan and non-UN climate change initiatives}

A number of international climate change-related initiatives have been started outside of the UNFCCC process, taking a different approach than the climate regime. The existence of a variety of governance arrangements could exert both a positive and negative influence on the efforts under the UNFCCC umbrella (Biermann et al. 2009, in press; Kanie 2007). On the positive side, overlapping approaches could lead to policy innovation through competition. On the other hand, the mere existence of these voluntary, non-binding arrangements could reduce the incentive to participate in the UN climate regime (McGee and Taplin 2006; van Asselt 2007). A host of different approaches to international climate policy could also reduce the overall consistency and coherence in global climate governance. Given these 
possible synergies and conflicts, developments outside of the UN climate regime are potentially relevant in shaping the future of global climate governance.

Although Japan actively participates in the post-2012 negotiations under the UNFCCC and the Kyoto Protocol, it is also involved in several international non-UN arrangements. Japan's role in the APP is described in the next section. Here we briefly discuss Japan's role in two other prominent non-UN fora: the G8 climate change dialogue and the Major Economies Meeting. ${ }^{5}$

In July 2005, the G8 initiated a three-year Dialogue on Climate Change, Clean Energy and Sustainable Development at a meeting in Gleneagles, Scotland (Karlsson 2009). ${ }^{6}$ The Dialogue not only included the G8 countries, but also engages five major developing countries-Brazil, China, India, Mexico and South Africa ('G8+5'). Also in this venue, long-term climate targets have received greater attention since the 2007 G8 Summit in Heiligendamm, Germany. Just before the summit, then Prime Minister Abe announced his 'Cool Earth 50' plan, which involved halving greenhouse gas emissions by 2050. This influenced the chair's summary of the summit, which stated that the G8 countries 'will consider seriously the decisions made by the European Union, Canada and Japan which include at least a halving of global emissions by 2050' (G8 2007). The process became of great importance to Japan when it hosted the G8 meeting in Toyako in July 2008. In the run-up to the summit, Japan tried to convince other G8 countries of its long-term vision, as it wanted to further develop the G8 statement from the previous year and present a result for 'serious consideration' of a long-term target under its chairmanship of the G8 Summit (Kanie 2008). It also promoted the usefulness of a sectoral approach in post-2012 climate policy (Point Carbon 2008). Although countries like Germany and the United Kingdom were supportive of the long-term goal, the Americans were more reluctant to accept a quantified long-term objective. Eventually, Japan more or less got its way, and the countries present-including the US - agreed 'to share (...) the vision (...) of the goal' to at least halve global emissions by 2050, although without specifying a base year (G8 2008, para. 23). On sectoral approaches, however, Japan did not achieve the full endorsement it had sought: G8 leaders merely regarded sectoral approaches as 'useful tools to improve energy efficiency and reduce emissions through dissemination of existing and new technologies in a manner compatible with economic growth' (G8 2008, para. 24).

Japan also participated in the Major Economies Meeting on Energy Security and Climate Change (MEM), which was launched by the United States in September 2007 and included 17 of the world's largest economies. Like the G8 process, the MEM became of significance to Japan in the run-up to its hosting of the G8 summit in 2008. At the meeting in Japan, countries agreed to 'promote the exchange of mitigation information and analysis on sectoral efficiency, the identification of national technology needs and voluntary, action-oriented international cooperation, and consider the role of cooperative sectoral approaches and sector-specific actions' (MEM 2008). For Japan, the APP is one of the examples of 'voluntary, action-oriented international cooperation'. 'There was thus some recognition of the usefulness of sectoral approaches, which Japan has also been pressing

\footnotetext{
${ }^{5}$ Other initiatives that Japan is involved in include: International Partnership for a Hydrogen Economy; Carbon Sequestration Leadership Forum; Global Nuclear Energy Partnership; International Partnership for Energy Efficiency Cooperation; Generation IV International Forum; and the International Energy Agency's Implementing Agreements.

6 The members of the G8 are Canada, France, Germany, Italy, Japan, Russia, the UK, and the US.

7 Discussion Paper, 2nd International workshop on sectoral emission reduction potential (Paris, 22nd October 2008), organised by government of Japan. Retrieved January 20, 2009, from http://www.env.go. jp/en/earth/cc/2nd_iwserp.html.
} 
for in its submissions to the UNFCCC (Vihma 2009, this issue). However, contrary to the G8 summit, the countries were not able to agree on a quantified long-term goal.

\subsection{Japan and the Asia-Pacific Partnership on Clean Development and Climate}

Japan's preference for sectoral approaches to climate change mitigation is arguably most visible in its participation in the Asia-Pacific Partnership on Clean Development and Climate (APP). The APP is a non-legally binding 'compact', aiming 'to meet (...) increased energy needs and associated challenges, including those related to air pollution, energy security, and greenhouse gas intensities' (APP Charter 2006, para. 1.1). The countries participating in the APP intend to achieve their goals through international cooperation with a view to the development, diffusion, deployment, and transfer of clean, efficient and cost-effective technologies (APP Charter 2006, para. 2.1.1).

Amongst the original six participating nations, Japan was the last one to join the APP, and only at the very last minute. ${ }^{8}$ Initially, the US White House Council on Environmental Quality feared that Japan would push for emission reduction targets and other 'Kyoto-like "anti-growth" " provisions. ${ }^{9}$ When it joined, the Japanese government emphasised that the APP was complementary to the Kyoto Protocol, and that it saw the APP as a way of promoting cooperation on climate and energy issues in the Asia-Pacific region. ${ }^{10}$ In a press statement, a representative of MOE stated that 'Kyoto remains in place, and the new initiative focuses on transferring technology to developing countries'. ${ }^{11}$ Furthermore, the Japanese government has referred to the APP as a positive example of (sectoral) cooperation in its submissions to the UNFCCC, emphasising its potential to diffuse clean and efficient technologies developed in Japan (e.g. UNFCCC 2008e). Moreover, it has argued that the practical work carried out in the context of the APP could form the basis for its 'cooperative sectoral approach' as proposed in the post-2012 negotiations. In particular, Japan suggests that the APP could support in the calculation of sectoral emission reduction potential (UNFCCC 2008d).

Although the partnership is not aimed at any technology or sector in particular, at the inaugural meeting held in Sydney in January 2006, eight areas were singled out for the establishment of 'task forces': (1) aluminium, (2) buildings and appliances, (3) cement, (4) cleaner fossil energy, (5) coal mining, (6) power generation and transmission, (7) renewable energy and distributed generation and (8) steel. Japan chairs the cement and steel task forces, which are both hosted by METI. In addition, Japan proposed to establish a new task force for the road transport sector in $2008 .^{12}$

A closer look at the various APP project descriptions shows that most projects are designed to facilitate transboundary sectoral interactions through, for example, exchanging specialists or conducting joint sector analyses. Despite its last-minute inclusion, Japan has become an avid proponent of the APP. The Japanese government (or in various cases a Japanese private organisation) is involved in over 30 projects. In the steel task force, Japan

\footnotetext{
8 Interview with WWF Japan representatives, 3 April 2007.

9 United States Department of State internal memo (on file with authors).

10 See, e.g., http://www.meti.go.jp/press/20061101001/app-press-release.pdf (in Japanese) (retrieved January 20, 2009).

11 MOE representative Akio Takemoto, quoted in Risk Spectrum Magazine. Retrieved January 20, 2009, from http://www.riskspectrum.com/_pdf/RSMagJan06.pdf, p. 8.

12 See Japan, Proposal for the establishment of an APP road transport Task Force (on file with authors).
} 
manages two projects. The first project seeks to review a number of indicators for energy saving in the sector. The second project consists of a 'diagnosis' of several steel plants in China and India (APP 2008). In the cement task force, Japan is involved in developing benchmarks, as well as analysing the efficiency of cement kilns in China and India (APP 2006). The Japanese government is optimistic about the information exchange through the APP: 'To maintain (...) high efficiency over a long period of time, the industry has developed various methodologies and know-how of operation, maintenance and management. Sharing them with the engineers of participating countries makes it possible for Japan to contribute to global-scale reduction in greenhouse gas emissions' (UNFCCC 2008 e, p. 12). It remains to be seen, however, whether and to what extent the data collection and information exchange activities eventually will lead to actual emission reductions.

Although the APP was agreed upon by governments, it foresees a crucial role for the private sector in the implementation of activities. By directly involving important actors that ultimately need to reduce their emissions-business and industry-it arguably addresses one of the weaknesses that critics have pointed out for the intergovernmental UN climate regime (Kellow 2006). The APP aims to promote information exchange within the private sector, and to establish procedures to identify, evaluate and to provide solutions for the challenges and obstacles faced in technology development. Nevertheless, the APP still requires the indispensable support of the various governments (Pezzey et al. 2006, p. 5).

On the one hand, the APP has a number of characteristics that fit well with the Japanese position in the post-2012 discussions in the UN climate regime: (1) its focus on emissions in specific large emitting sectors that are subject to international competition, (2) the emphasis on technological innovation and the transfer of clean technologies and practices, and (3) the participation of other major emitters (China, India and the US) in climate change mitigation efforts. On the other hand, it also lacks some of the elements that Japan has embraced in the UN context. Notably, APP activities are not linked to any long-term objective for global emission reductions. Whereas a long-term 'vision' is now being discussed in the UNFCCC, the G8 and the MEM processes, the APP refrains from mentioning any quantified objective, not even as an aspirational target. Furthermore, the sectoral approach of the APP differs from the one that Japan advocates in the UNFCCC discussions. In the APP, sectoral activities are voluntary in nature, whereas Japan's proposal in the climate regime intends to use sectoral analysis as the basis for a country's (legally binding) commitments (see UNFCCC 2008c). The differences between approaches of the APP and the UN climate regime raise the question of why the country is active in the different fora. The next section examines three possible explanations for Japan's participation in the APP alongside the UN negotiations.

\section{Explaining Japan's participation in the UN climate regime and the APP}

\subsection{Interest group politics: engaging business while reassuring civil society}

One of the first plausible explanations for Japan's choice to participate in both the Kyoto Protocol and the APP lies in domestic interest group politics. Japanese industry, of which about $80 \%$ is united in the Federation of Economic Organizations (FEO or Nippon Keidanren), have historically been a powerful interest group, with strong ties to the leading political party (LDP) and METI (Okimoto 1989). Their power is also visible in domestic climate politics, as Fisher (2004, p. 73) argues: 'The regulation of climate change in Japan 
is a case in point that the government has only taken steps that are approved by industry'. In the 1990s, Keidanren pre-empted the outcomes of the Kyoto negotiations by announcing its own voluntary action plan in 1997. The plan was established at least in part out of fear of possible government regulations (Matsumura 2000). Although Keidanren did not explicitly consult with the government in drawing up the plan, the government later approved it (Schroeder 2003), and policy measures for the industry sector in Japan have been based on Keidanren's voluntary action plan (Tiberghien and Schreurs 2007).

Keidanren has strongly opposed government interventions, including the use of economic instruments such as carbon taxes and emissions trading (Nippon Keidanren 2007). Their main rationale is that the costs imposed would damage the competitiveness of Japanese industry on the international market, especially given a situation where both the largest import (China) and export (the US) markets are not subject to emission caps. This situation would arguably result in the relocation of production and jobs abroad, and would thus harm the overall economy (Miyaoka 2004). After the US withdrew from Kyoto in 2001, industry representatives called the Protocol a failure for allowing the largest emitter to walk away so easily (Nippon Keidanren 2001). Critics from industry also viewed the Kyoto Protocol as unfair, as some EU Member States, notably Germany and the UK, had achieved emission reductions due to non-climate policy related political and economic changes, and the EU could use the 1990 base year of the Protocol to its advantage. ${ }^{13}$ Japanese industry were opposed to the use of a 1990 baseline, insisting that Japanese energy efficiency improvements and energy substitutions occurred mainly in the 1970s in response to the two oil shocks in that decade. Hence, for Japan, it would have been more beneficial to compare emissions with the 1970s, or by using other criteria, such as sectoral emissions reduction potential, as a yardstick for abatement.

This debate intensified in 2009, when the discussions over a Japanese mid-term target were mounting. On 17 March, Keidanren and its associated members published a full page advertisement in major newspapers in Japan, arguing to re-consider the costs of greenhouse gas emission reductions on the basis of Japan's high level of industrial energy efficiency. It also argued that out of the six options for a Japanese mid-term target-ranging from a $4 \%$ increase to a $25 \%$ emissions reduction in 2020 - the $4 \%$ increase of emissions would be the most appropriate.

Given the above lines of thought, it is perhaps not surprising to see why industry representatives in Japan have been enthusiastic about the APP, and even argue that the APP could form the basis for a global sectoral approach (Nippon Keidanren 2007; Sameshima 2007). They emphasise the importance of the sharing of know-how and best available technologies, and applying common benchmarks at the sector level. The APP displays some features that fit well with Keidanren's approach to climate change mitigation, or at least suit their preferences better than the proposed 'cooperative sectoral approach' in the UNFCCC. First, the voluntary nature of the APP matches the voluntary approach Keidanren has implemented since the mid-1990s. ${ }^{14}$ Second, the APP includes the US and China, thereby mitigating competitiveness concerns of Japanese industry. Third, the public-private nature of the APP allows business and industry representatives to directly

\footnotetext{
13 There are a number of reasons why the base year of 1990 has turned out to be advantageous for the European Union. First, the re-unification of Germany coincided with a collapse of the former Eastern Germany economy, with subsequent falling emissions. Second, the UK also profited from windfall emissions' decreases after its switch from coal to gas in the early 1990s.

14 It should be noted, however, that despite the voluntary nature of Keidanren's action plan, their commitments function as if they were legally binding (Fisher 2004).
} 
engage in its implementation, in cooperation with governments. As task-force activities require detailed information about sectoral emissions, technologies and mitigation potential and are thus inherently technical, the involvement of business and industry actors is key. Fourth, the APP builds partly on existing business and industry networks, such as the World Steel Association and the Cement Sustainability Initiative. Business actors thus see the APP as an alternative forum through which they can influence the design of post-2012 climate policy more directly than in the UNFCCC. ${ }^{15}$

At the same time, there is some pressure to stay involved in the UN process. Although environmental NGOs have not been as powerful and influential as in other countries (Foljanty-Jost 2005), their voice is increasingly being heard in some parts of the government (Fisher 2004; Tiberghien and Schreurs 2007). Both domestic and international environmental NGOs in Japan are sceptical of the APP, instead supporting Kyoto's targetsand-timetables approach. In particular, they have argued that the APP is aimed at deploying already existing technologies, and that the transfer of clean technologies requires market incentives that the APP does not offer. ${ }^{16}$ Furthermore, there is a high degree of public awareness of the climate change problem and the Kyoto Protocol (e.g. Cabinet Office, Japanese Government 2001). Respondents to a poll by the Ministry of Foreign Affairs were strongly in favour of the Japanese government taking a leading role on the issue in the international community (MOFA 2005). Finally, nationwide newspapers such as the Asahi shinbun and the Mainichi shinbun repeatedly argue in their editorials that staying within the UN process is the best way forward to tackle climate change.

In sum, from the perspective of interest group politics, Japan's continued active participation in the APP can be explained by the fact that the APP has received support from the country's powerful business and industry lobby. At the same time, Japan's continuing participation in the UNFCCC is broadly supported by other domestic actors including the public and media, as well as environmental NGOs.

\subsection{Bureaucratic politics: accommodating different ministries}

A second explanation relates to politics at the government level. As we argued in Sect. 2, Japanese climate-policy making in the 1990s has been characterised by rivalry between METI and MOE. Since the period leading up to the Kyoto conference, the basic decisionmaking procedures on climate policy in Japan have stayed the same and ' $[\mathrm{t}]$ he same ministerial battle lines have remained to this day' (Tiberghien and Schreurs 2007, p. 77). Each ministry has its own networks with 'interlocking self-interests among bureaucracy, politicians and interest groups based on reciprocal political exchange' (Oshitani 2006, p. 67-68), and each ministry is protecting its own realm of competence. Japan thus faces the same challenges with regard to the post-2012 process that it had to deal with in the 1990s in getting to a national position on the Kyoto Protocol.

Ever since the United States' withdrawal from the Kyoto Protocol, METI, backed by Keidanren, has argued that a future institutional framework does not necessarily have to be similar to the Kyoto-type cap-and-trade approach. METI's 'Special Committee on a Future Framework for Addressing Climate Change under Industrial Structure Council', which is instrumental in devising the ministry's climate policy, published a report during COP-10 in 2004 (METI 2004), reflecting critical views of the Kyoto Protocol, and arguing that Japan's

\footnotetext{
15 Interview with NIES researchers, 4 April 2007.

16 See NGO challenge to the Asia Pacific Partnership on Clean Development and Climate. Retrieved January 20, 2009, from http://www.cana.net.au/documents/NGO_statement_APPCDC_100106_final.pdf.
} 
emission reduction target was proving to be difficult to achieve, especially for the industrial sector. It argued that emissions were rising, and that the policies in place did not seem to be sufficient to change this trend. Based on METI's critical view of the Kyoto Protocol, the future climate regime should include broad participation by all the major emitters. In order to ensure a level playing field for the various industries, it was considered necessary to apply common standards to international competitors. The report argued that incentives for the development and deployment of climate-friendly technologies would be greatest when such a common standard was shared by both industrialised countries and developing countries (METI 2004). In addition to METI's critical view of the Kyoto Protocol, the ministry supports the APP as it directly involves private actors. ${ }^{17}$ Furthermore, as the host of two task forces (cement and steel), METI has a direct interest in continuing the partnership. ${ }^{18}$

While METI drafted its ideas for future climate policy, MOE devised its own post-2012 strategy (MOE 2004). The ministry acknowledged the Kyoto Protocol's influence on Japan's domestic climate policy. If no agreement had been reached in Kyoto, there would not have been any pressure to set up the Global Warming Prevention Headquarters in 1997. Furthermore, important parts of domestic climate policy were established after 1997, and it might have been impossible to agree upon in the absence of the quantified emission reduction target under the Kyoto Protocol. With a view to further mitigation action, the report argued that some kind of stringent commitment would be necessary also in the next round of negotiations. Although this did not necessarily have to be an absolute emission reduction target, some kind of quantified figure was seen as necessary. The report still welcomed any other ideas that would be more environmentally effective, thereby not completely excluding other approaches than targets-and-timetables. At the same time, it considered participation of other large emitters indispensable in reaching the ultimate objective set out in Article 2 UNFCCC. While MOE thus clearly preferred the Kyoto approach, it also did not discard other approaches like the APP altogether.

The primary concern for the third ministry involved, MOFA, has been to promote Japan's environmental reputation abroad. Since the 1990s, environmental policy was considered one of the rare fields where Japan could exert international leadership. Given its World War II history, and particularly the constitutional restriction that the country will not hold any military power, international security and military issues have been controversial domestically, whereas environmental diplomacy has been regarded as politically neutral. The decision to host the Kyoto conference in 1997 fits well with this line of thinking. MOFA's responsibility for safeguarding Japan's international reputation in environmental diplomacy has been challenging given the fragmented domestic constituency (Hattori 1999). However, with respect to the APP, it has tended to side with METI, mainly to uphold its relations with the United States. As Tiberghien and Schreurs (2007, p. 88) explain: 'while having ratified the Kyoto Protocol (...) the powerful METI and MOFA have continued to search for other policy alternatives that powerful domestic interests and Japan's most important ally, the US, are willing to accept and support'.

Although there are some apparent differences between the ministries, there may also be a common strategic element underlying their implicit support of Japan's participation in both the APP and the UN climate regime, which is related to the possibility of creating synergies between the two (see also Vihma 2009, this issue). First, Japan views the APP as an appropriate mechanism for getting major emitters involved in climate action (UNFCCC

\footnotetext{
17 Interview with MOE official, 7 April 2007.

18 Interview with MOE official, 7 April 2007.
} 
2008e). In fact, this was one of the primary reasons why METI, which holds the main responsibility for the Partnership, decided to join. ${ }^{19}$ Although the APP does not necessarily result in additional emission reductions in these countries, they are formally treated as equals in the context of the Partnership. Second, even though the sectoral approach as promoted by the APP may not be the same as the sectoral approach advocated in Japan's submissions to the UNFCCC, the APP could lay the groundwork for a future sectoral approach in the climate regime, through sectoral data collection and capacity building (UNFCCC 2008d).

In short, METI argues that Kyoto should be revisited and climate policy should be based on technology development and deployment, which is in line with the approach taken by the APP. MOE, on the other hand, continues to emphasise its support of the targets-andtimetables approach taken by the Kyoto Protocol, although is not inherently opposed to alternative approaches such as the APP. MOFA tries to maintain Japan's reputation in environmental diplomacy, but does not reject its participation in multiple fora if this is seen as important for safeguarding good relations with its allies. While the Cabinet Office got involved in ministerial deliberations before the Kyoto conference, interventions by the office can so far only be witnessed in the debate over the mid-term target. Despite apparent differences between these ministries, however, it can be argued that they hold the common view that the APP could support achieving Japan's negotiation objectives in the climate regime.

\subsection{International politics: mediating between the United States and the rest of the world}

A third perspective that can help understand Japan's apparently ambiguous position looks at developments and relations at the international level (cf. Fisher 2004, p. 66). Various pressures come from other actors in the international climate regime, including the US and the EU. Already in the creation of the climate regime, Japan 'tried to take a middle course between environmentally passive America and active Europe and to play a mediating role in coordinating their different stances' (Miyaoka 2004, p. 74).

Japan attaches great importance to keeping a good relationship with the United States, not only in the area of climate policy, but also with respect to security and economic issues (Inoguchi 1993; Iida 1999; Ikenberry and Inoguchi; 2003; Kawashima 2003). In the climate change negotiations, Japan originally sided with the US on several occasions, although the countries' positions have not always been aligned (Matsumura 2000). In the negotiations on the UNFCCC, Japan initially opposed a system of targets-and-timetables together with the US and China. However, it eventually accepted (non-legally binding) common targets-i.e. the UNFCCC's aspirational goal to stabilise emissions by 2000 . Similarly, in the negotiations for the Kyoto Protocol, Japan was a member of the JUSCANZ $^{20}$ negotiation coalition, which originally opposed binding caps.

However, Japan has increasingly taken up an intermediary role, especially since the US rejection of the Kyoto Protocol (Kanie 2006). For example, the compromise text of paragraph 38 of the Johannesburg Plan of Action, stating that 'States that have ratified the Kyoto Protocol strongly urge States that have not already done so to ratify it in a timely manner' stems originally from a Japanese proposal (Kanie 2003). The same attitude could

\footnotetext{
19 Interview with METI official, 31 March 2009.

20 The JUSCANZ bloc consisted of Japan, the United States, Canada, Australia and New Zealand.
} 
be witnessed at COP-6bis (2001), which was held right after the US rejection, and where Japan's position was of vital importance for the future of the treaty (Hamanaka 2006).

In conclusion, Japan's foreign policy on climate change is influenced by historical and economic ties with the US. However, compared to conventional diplomacy, Japan's ties in international climate politics are closer with the EU. Both the EU and Japan ratified the Kyoto Protocol, and have been firm supporters of the treaty, although for different reasons. Whereas the EU wants to promote the Protocol in terms of environmental integrity, Japan has above all a symbolic tie with the treaty, given the place of its inception (Kanie 2006; Tiberghien and Schreurs 2007). By joining the APP, Japan has been able to continue its cooperation with the US - as well as with important Asian trade competitors/partners-on climate change issues, while at the same time staying involved in the post-2012 discussions under the UN climate regime.

\section{Concluding thoughts}

This article sought to explore the reasons for Japan's simultaneous participation in the UN climate regime and the Asia-Pacific Partnership, two institutional arrangements that some have argued to be at odds with each other. Although Japan only joined the rank of the founders of the APP at the last minute, it has been particularly active in the implementation of the Partnership's projects. At the same time, Japan clearly has not given up on the UN climate regime and the treaty that bears the name of its former capital, the Kyoto Protocol.

What at first may be seen as an ambiguous decision can in fact be explained by a number of factors, as summarised in Table 2. At the domestic level, stakeholders have expressed both sympathy and scepticism about the APP. At the government level, the key Ministries have pursued diverging post-2012 strategies, emphasising different design elements of a future climate agreement. However, they seem to share the view that the APP could support the future climate regime, by building on the sectoral activities undertaken in the partnership. Finally, Japan's decisions are influenced by its determination to engage with various other actors at the international level, including the US and the EU. These explanations at various levels provide reasonable arguments for why Japan would join, and continue its participation in the APP, while at the same time not turning its back to the UNFCCC negotiation process following the US rejection to the Kyoto Protocol.

Table 2 Overview of explanations of Japan's participation in the UN climate regime and the APP

\begin{tabular}{cl}
\hline Interest group politics & Keidanren opposed to Kyoto targets-and-timetables and emissions trading \\
& NGOs sceptical of APP \\
& Public opinion favourable to Kyoto \\
Bureaucratic politics & METI critical of fairness and effectiveness of Kyoto; hosts APP task forces \\
& MOE cannot turn its back on Kyoto; favours targets-and-timetables; \\
no rejection of APP \\
MOFA supportive of initiative involving the US \\
All ministries acknowledge possible synergies between APP and UN climate regime \\
Japan seeking to re-engage the US in UNFCCC, and mediating between \\
the EU and the US \\
Seeking to involve major emitters (China, India)
\end{tabular}


In conclusion, we would argue that Japan's position in international climate policy is primarily the result of trying to accommodate conflicting viewpoints at the domestic and international levels, which is in line with previous research on Japan's policy-making process (Kusano 1983; Hashimoto 1999; Shindo 2001).

The impact of Japan's dual participation on its carbon emission reductions is not yet clear at this stage, as the APP has only recently started, and it will be difficult to attribute specific additional emission reductions to the effects of the Partnership (Karlsson-Vinkhuyzen and van Asselt 2009, this issue). However, there may be some synergies in terms of data collection between the UNFCCC and the APP. While data collection under the UNFCCC is useful for sketching an overall picture through emissions inventories, the APP could provide practical information to enable technology transfer and deployment. Exploiting this synergy could allow Japan to ensure complementarity between the two approaches.

At the time of writing, the shape and substance of the post-2012 institutional framework for international climate policy remains unclear. However, what is clear is that a sectoral approach to climate policy constitutes a radical departure from the current approach taken by the Kyoto Protocol (McGee and Taplin 2009, this issue), even though Japan has argued that its 'cooperative sectoral approach' may be compatible with quantified national emission reduction targets. However, sectoral approaches inevitably require the participation of private actors, which does not fit well with the character of negotiations between sovereign nation states. Furthermore, sectoral approaches involve activities that may be too technical to be dealt with by bureaucrats at the international level, including data collection on emissions, projections of mitigation potential and the identification of state-of-the-art technologies. However, there might be a role for public-private initiatives such as the APP to support a sectoral approach within the UN climate regime to implement concrete activities at the sector level, including sectors in both developed and developing countries. In order for the APP and similar initiatives to constructively support the UNFCCC's objectives, a strong link would be required between the two. This could even take the shape of a formal provision in a new UN climate treaty that requests countries participating in the APP to report on progress as part of an obligation to measure, report and verify mitigation actions. If such a synergetic institutional architecture is achieved, then Japan's ambiguous position towards the UNFCCC and APP might be positively evaluated.

Acknowledgements The authors would like to thank the various anonymous interviewees for sharing their insights on this issue. We would also like to thank Sylvia Karlsson-Vinkhuyzen and Constanze Haug for their comments on earlier drafts of this article. In addition, two anonymous reviewers provided helpful comments (All errors, however, remain our own). The research was in part conducted under the project Adaptation and Mitigation Strategies: Supporting European Climate Policy (ADAM), financed by DG Research of the European Commission under the Sixth Framework Programme 2002-2006, Priority 1.1.6.3, Global Change and Ecosystems. Harro van Asselt would furthermore like to thank the Canon Foundation Europe for the financial support for the research stay at the Tokyo Institute of Technology.

Open Access This article is distributed under the terms of the Creative Commons Attribution Noncommercial License which permits any noncommercial use, distribution, and reproduction in any medium, provided the original author(s) and source are credited.

\section{References}

APP Charter. (2006). Charter for the Asia-Pacific Partnership on Clean Development and Climate. Retrieved January 20, 2009, from http://www.asiapacificpartnership.org. 
APP. (2006). Asia Pacific Partnership on Clean Development and Climate, Cement Task Force Action Plan. Retrieved January 20, 2009, from http://asiapacificpartnership.org/APP\%20Action\%20Plans/Cement\% 20Task\%20Force\%20Action\%20Plan\%20_27\%20Oct\%2006.pdf.

APP. (2008). Asia Pacific Partnership on Clean Development and Climate, Steel Task Force Action Plan. Retrieved January 20, 2009, from http://asiapacificpartnership.org/APP\%20Action\%20Plans/Steel\% 20Task\%20Force\%20Action\%20Plan\%20030507.pdf.

Bäckstrand, K. (2008). Accountability of networked climate governance: the rise of transnational climate partnerships. Global Environmental Politics, 8(3), 74-102.

Baumert, K. A., Herzog, T., \& Pershing, J. (2005). Navigating the numbers: Greenhouse gas data and international climate policy. Washington, DC: World Resources Institute.

Biermann, F., Pattberg, P., van Asselt, H., \& Zelli, F. (2009). The fragmentation of global governance architectures: a framework for analysis. Global Environmental Politics, 9(4) (in press).

Broadbent, J. P. (2002). From heat to light?: Japan's changing response to global warming. In J. D. Montgomery \& N. Glazer (Eds.), Sovereignty under challenge (pp. 109-142). New Brunswick, NJ: Transaction Publishers.

Cabinet Office, Japanese Government. (2001). Opinion poll on prevention of global warming and life style. Retrieved January 20, 2009, from http://www8.cao.go.jp/survey/h13/h13-ondanka/index.html.

Christoff, P., \& Eckersley, R. (2007). The Kyoto Protocol and the Asia Pacific Partnership on Clean Development and Climate. In T. Bonyhady \& P. Christoff (Eds.), Climate law in Australia (pp. 32-45). Sydney: Federation Press.

Clémençon, R. (2008). The Bali road map: A first step on the difficult journey to a post-Kyoto Protocol agreement. Journal of Environment and Development, 17(1), 70-94.

Fisher, D. (2004). National governance and the global climate change regime. Lanham: Rowman \& Littlefield.

Foljanty-Jost, G. (2005). NGOs in environmental networks in Germany and Japan: The question of power and influence. Social Science Japan Journal, 8(1), 103-117.

Fukuda, Y. (2008). In pursuit of “Japan as a Low-carbon Society”, speech by H.E. Mr Yasuo Fukuda, Prime Minister at the Japan Press Club (9 June 2008). Retrieved January 20, 2009, from http://www. kantei.go.jp/foreign/hukudaspeech/2008/06/09speech_e.html.

G8. (2007). Chair's Summary, Heiligendamm, 8 June 2007. Retrieved January 20, 2009, from http://www.governo.it/GovernoInforma/Dossier/g8_hokkaido/conclusioni2007.pdf.

G8. (2008). G8 declaration on environment and climate change. Retrieved January 20, 2009, from http://www.whitehouse.gov/news/releases/2008/07/20080708-3.html.

Hamanaka, H. (2006). Kyoto giteisho o meguru kokusai kosho: COP-3 ikou no kosho keii (the international negotiations for the Kyoto Protocol). Tokyo: Keio Gijuku Daigaku Shuppankai.

Hashimoto, K. (Ed.). (1999). Nihon no gaiko seisaku Kettei Yoin (Domestic determinants of Japanese foreign policy). Tokyo: PHP Interface.

Hattori, T. (1999). The road to the Kyoto conference: An assessment of the Japanese two-dimensional negotiation. International Negotiation, 4(2), 167-195.

Iida, K. (1999). International monetary cooperation among the United States, Japan, and Germany. Berlin: Springer.

Ikenberry, G. J., \& Inoguchi, T. (Eds.). (2003). Reinventing the alliance: U.S.-Japan security partnership in an Era of Change. Basingstoke: Palgrave Macmillan.

Inoguchi, T. (1993). Japan's foreign policy in an era of global change. London: Continuum International Publishing.

Jagers, S. C., \& Stripple, J. (2003). Climate Governance beyond the State. Global Governance: A Review of Multilateralism and International Organizations, 9(3), 385-399.

Kameyama, Y. (2008). The "beyond 2012" debate in Japan. In Y. Kameyama, A. P. Sari, M. H. Soejachmoen, \& N. Kanie (Eds.), Climate change in Asia: Perspectives on the future climate regime (pp. 120-131). Tokyo: United Nations University Press.

Kanie, N. (2003). Johannesburg Summit and governance for sustainable development. Environmental Research Quarterly, 128, 37-44.

Kanie, N. (2006). International institutions beyond Kyoto: towards diffused climate change governance. International Affairs, 552, 47-59.

Kanie, N. (2007). Governance with multilateral environmental agreements: A healthy or ill-equipped fragmentation? In W. Hoffmann \& L. Swart (Eds.), Global environmental governance (pp. 67-86). New York: Center for UN Reform Education.

Kanie, N. (2008). '2013 problems' in international politics on climate change: Can Japan lead the debate over institutional architecture? SEKAI, 780, 215-227. 
Karlsson, S. (2009, February). G8 climate action from Gleneagles to Hokkaido: Dying flare or lasting flame? Paper presented at the International Studies Association Conference, New York.

Karlsson-Vinkhuyzen, S., \& van Asselt, H. (2009). Exploring and explaining the Asia-Pacific Partnership on Clean Development and Climate. International Environmental Agreements: Politics, Law and Economics, 9(3), this issue.

Kawashima, Y. (2000). Japan's decision-making about climate change problems: Comparative study of decisions in 1990 and in 1997. Environmental Economics and Policy Studies, 3(1), 29-57.

Kawashima, Y. (2003). Japanese foreign policy at the crossroads. Washington, DC: Brookings Institution Press.

Kellow, A. (2006). A new process for negotiating multilateral environmental agreements? The Asia-Pacific Climate Partnership beyond Kyoto. Australian Journal of International Affairs, 60(2), 287-303.

Kusano, A. (1983). Nichibei orange kosho: Keizai masatsu wo miru atarashii shiten (Orange Negotiation between Japan and the U.S.: A new perspective on economic friction). Tokyo: Nihon Keizai Shinbun Sha.

Lawrence, P. (2007). The Asia Pacific Partnership on Clean Development and Climate (AP6): A distraction to the Kyoto process or a viable alternative? Asia Pacific Journal of Environmental Law, 10(3/4), 183-209.

Matsumura, H. (2000). Japan and the Kyoto Protocol, conditions for ratification. London: The Royal Institute of International Affairs.

McGee, J., \& Taplin, R. (2006). The Asia-Pacific Partnership on Clean Development and Climate: A complement or competitor to the Kyoto Protocol? Global Change, Peace \& Security, 18(3), 173-192.

McGee, J., \& Taplin, R. (2009). The role of the Asia Pacific Partnership in discursive contestation of the international climate regime. International Environmental Agreements: Politics, Law and Economics, 9(3). doi:10.1007/s10784-009-9101-2.

MEM. (2008). Declaration of leaders meeting of Major Economies on Energy Security and Climate Change, Hokkaido, Toyako, 9 July 2008. Retrieved January 20, 2009, from http://www.g8.utoronto.ca/summit/ 2008hokkaido/2008-mem.html.

METI. (2004). An interim report by special committee on a future framework for addressing climate change under Industrial Structure Council, METI. Retrieved January 20, 2009, from http://www.meti.go.jp/ feedback/downloadfiles/i41022fj.pdf.

Miyaoka, I. (2004). Japan's conciliation with the United States in climate change negotiations. International Relations of the Asia-Pacific, 4, 73-96.

MOE. (1998). Guidelines for measures to prevent global warming. Tokyo: Ministry of the Environment. Retrieved January 20, 2009, from http://www.env.go.jp/en/earth/cc/gw/index.html.

MOE. (2004). Climate regime beyond 2012: Key perspectives. Interim report by the Sub-Committee for International Climate Change Strategy, MOE. Retrieved January 20, 2009, from http://www.env.go.jp /council/06earth/r064-02/e_full.pdf.

MOE. (2008). On Japan's greenhouse gas emission in 2006. Retrieved January 20, 2009, from http://www. env.go.jp/press/press.php?serial=9704.

MOFA. (2005). Opinion poll on global issues. Retrieved January 20, 2009, from http://www.mofa.go.jp/ MOFAJ/gaiko/kankyo/i_chosa.html.

MOFA. (2007). The outline and evaluation of the first meeting of Major Economies Meeting on Energy Security and Climate Change. Retrieved January 20, 2009, from http://www.mofa.go.jp/mofaj/gaiko/ kankyo/kiko/hl_07_gh2.html.

Nippon Keidanren. (2001). Speech by Mr. Takashi Imai, Former Chairperson of Keidanren, regarding the issue of global warming. Retrieved January 20, 2009, from http://www.keidanren.or.jp/japanese/ speech/comment/2001/com0615.html.

Nippon Keidanren. (2007). Keidanren's proposal for a post-2012 international framework on preventing climate change. Retrieved January 20, 2009, from http://www.keidanren.or.jp/english/policy/2007/ 080.html.

Okimoto, D. I. (1989). Between MITI and the market: Japanese industrial policy for high technology. Stanford, CA: Stanford University Press.

Oshitani, S. (2006). Global warming policy in Japan and Britain. Interactions between institutions and issue characteristics. Manchester: Manchester University Press.

Pattberg, P., \& Stripple, J. (2008). Beyond the public and private divide: remapping transnational climate governance in the 21st century. International Environmental Agreements: Politics, Law and Economics, 8(4), 367-388.

Pezzey, J. C. V., Jotzo, F., \& Quiggin, J. (2006). Fiddling while carbon burns: why climate policy needs pervasive emission pricing as well as technology promotion. Australian National University Economics and Environment Network Working Paper EEN0611. Canberra: Australian National University. 
Point Carbon. (2008). G8 Environment Ministers meet for climate talks (23 May 2008).

Rajamani, L. (2008). From Berlin to Bali and beyond: Killing Kyoto softly. International and Comparative Law Quarterly, 57, 909-939.

Sameshima, F. (2007). Toward effective prevention of global warming: Nippon Keidanren's proposals on a post-Kyoto Protocol framework. Japan Economic Currents, 68, 1-6.

Schreurs, M. A. (2002). Environmental politics in Japan, Germany, and the United States. Cambridge: Cambridge University Press.

Schreurs, M. A. (2004). Assessing Japan's role as a global environmental leader. Policy \& Society, 23(1), 88-110.

Schroeder, H. (2003). Climate change policy in Japan. From dusk to dawn. Ph.D. thesis, Freie Universität, Berlin.

Shindo, M. (2001). Kougi gendai nihon no gyosei (Introduction to the government system of Modern Japan). Tokyo: Tokyo University Press.

Takeuchi, K. (1998). Chikyu ondanka no seiji-gaku (Politics on global warming). Tokyo: Asahi-Sensho.

Tiberghien, Y., \& Schreurs, M. A. (2007). High noon in Japan: Embedded symbolism and post-2001 Kyoto Protocol politics. Global Environmental Politics, 7(4), 70-91.

UNFCCC. (2007). Scope and content of the second review under Article 9 of the Kyoto Protocol and the preparations required for conducting the review. Submissions from Parties. Addendum. UN Doc. FCCC/KP/CMP/2007/MISC.1/Add.2.

UNFCCC. (2008a). Bali Action Plan, Decision 1/CP.13. UN Doc. FCCC/CP/2007/6/Add.1.

UNFCCC. (2008b). Report of the Ad Hoc Working Group on Further Commitments for Annex I Parties under the Kyoto Protocol on its resumed fourth session. UN Doc FCCC/KP/AWG/2007/5.

UNFCCC. (2008c). Ideas and proposals on the elements contained in paragraph 1 of the Bali Action Plan. Submissions from Parties. UN Doc. FCCC/AWGLCA/2008/MISC.2.

UNFCCC. (2008d). Ideas and proposals on the elements contained in paragraph 1 of the Bali Action Plan. Submissions from Parties. Addendum. Part II. UN Doc. FCCC/AWGLCA/2008/MISC.5/Add.2 (Part II).

UNFCCC. (2008e). Views and information on the means to achieve mitigation objectives of Annex I Parties. Submissions from Parties. Addendum. UN Doc. FCCC/KP/AWG/2008/MISC.1/Add.1.

van Asselt, H. (2007). From UN-ity to diversity? The UNFCCC, the Asia-Pacific Partnership, and the future of international law on climate change. Carbon and Climate Law Review, 1(1), 17-28.

Vihma, A. (2009). Friendly neighbor or Trojan horse? Assessing the interaction of soft law initiatives and the UN climate regime. International Environmental Agreements: Politics, Law and Economics, 9(3). doi:10.1007/s10784-009-9100-3. 